\title{
Enhanced Neurotrophin-Induced Axon Growth in Myelinated Portions of the CNS in Mice Lacking the p75 Neurotrophin Receptor
}

\author{
Gregory S. Walsh, ${ }^{1}$ Karmen M. Krol, ${ }^{1}$ Keith A. Crutcher, ${ }^{2}$ and Michael D. Kawaja ${ }^{1}$ \\ ${ }^{1}$ Department of Anatomy and Cell Biology, Queen's University, Kingston, Ontario, Canada K7L 3N6, and '2Department of \\ Neurosurgery, University of Cincinnati Medical Center, Cincinnati, Ohio 45267-0515
}

\begin{abstract}
Axonal growth in the adult mammalian CNS is limited because of inhibitory influences of the glial environment and/or a lack of growth-promoting molecules. Here, we investigate whether supplementation of nerve growth factor (NGF) to the CNS during postnatal development and into adulthood can support the growth of sympathetic axons within myelinated portions of the maturing brain. We have also asked whether p $75^{\text {NTR }}$ plays a role in this NGF-induced axon growth. To address these questions we used two lines of transgenic mice overexpressing NGF centrally, with or without functional expression of p $75^{\text {NTR }}$ (NGF/p75 $75^{+/}$and NGF/p75 ${ }^{-1-}$ mice, respectively). Sympathetic axons invade the myelinated portions of the cerebellum, beginning shortly before the second week of postnatal life, in both lines of NGF transgenic mice. Despite the presence of central myelin, these sympathetic axons continue to sprout and
\end{abstract}

increase in density between postnatal days 14 and 100, resulting in a dense plexus of sympathetic fibers within this myelinated environment. Surprisingly, the growth response of sympathetic fibers into the cerebellar white matter of NGF/p $75^{-1-}$ mice is enhanced, such that both the density and extent of axon ingrowth are increased, compared with age-matched $\mathrm{NGF} / \mathrm{p} 75^{+/+}$mice. These dissimilar growth responses cannot be attributed to differences in cerebellar levels of NGF protein or sympathetic neuron numbers between NGF/p $75^{+/+}$and NGF/ $\mathrm{p} 75^{-1-}$ mice. Our data provide evidence demonstrating that growth factors are capable of overcoming the inhibitory influences of central myelin in the adult CNS and that neutralization of the p75 NTR may further enhance this growth response.

Key words: nerve growth factor; p75 neurotrophin receptor; myelin; axon growth; sympathetic; cerebellum
One of the greatest obstacles that hampers restoration of neural function after injury is the lack of sustainable axon regrowth in myelinated structures of the adult mammalian CNS. Myelin produced by oligodendrocytes in the brain and spinal cord can inhibit axon growth both in vitro and in vivo (Caroni and Schwab, 1988a; Crutcher, 1989; Schnell and Schwab, 1990; Schwab, 1990; Bregman et al., 1995; Lozano et al., 1995; Schwab and Brösamle, 1997). Glial scars, which form shortly after the integrity of the brain or spinal cord has been breached, serve as both a physical (Reier and Houle, 1988; Reier et al., 1989) and chemical (McKeon et al., 1991; Fawcett, 1994) barrier to axons attempting to regrow after damage. It has also been suggested that an inadequate supply of growth-promoting molecules may also contribute to a lack of new axon extension in the damaged CNS (Schwartz et al., 1989).

The neurotrophin family of growth factors, including nerve growth factor (NGF), brain-derived neurotrophic factor (BDNF), and neurotrophin-3 (NT-3), has been shown to influence axon sprouting and regeneration in the mammalian CNS. Menesini-Chen et al. (1978) reported that intraparenchymal in-

\footnotetext{
Received Sept. 16, 1998; revised March 8, 1999; accepted March 9, 1999.

This work was supported by grants from the Botterell Foundation and Advisory Research Committee at Queen's University (to M.D.K.) and National Institutes of Health Grant NS17131 (to K.A.C.). G.S.W. was supported by a studentship from the Rick Hansen Man in Motion Foundation. We are grateful to Janet Elliott for the RT-PCR, Krissy Klosowski for the ELISA determinations of NGF, Verna Norkum for the cryostat and ultramicrotome sectioning, and Robert Temkin for the photography.

Correspondence should be addressed to Dr. Michael D. Kawaja, Department of Anatomy and Cell Biology, Botterell Hall, 9th Floor, Queen's University, Kingston, Ontario, Canada K7L 3N6.

Copyright (C) 1999 Society for Neuroscience $\quad 0270-6474 / 99 / 194155-14 \$ 05.00 / 0$
}

fusions of NGF in the neonatal rat brain promote the directional growth of sympathetic axons toward the site of injection within yet-to-be myelinated tracts. This neurotropism, however, could not be induced through the myelinated tracts of adult animals. Sympathetic fibers have been shown to grow into the NGF-rich, denervated hippocampus of adult mammals, but this new growth is confined to the gray matter (Crutcher et al., 1981; Crutcher and Chandler, 1985; Crutcher and Marfurt, 1988). Recent investigations have demonstrated that applications of BDNF and NT-3 can also stimulate the extension of new axonal processes of CNS neurons through damaged areas of the brain and spinal cord, but only over short distances and usually confined to gray matter regions (Logan et al., 1994; Schnell et al., 1994; Mamounas et al., 1995; Xu et al., 1995; Sawai et al., 1996; Bregman et al., 1997; Grill et al., 1997; Ye and Houle, 1997; Schwab and Brösamle, 1997). Even when the inhibitory actions of central myelin are neutralized, new axons growing in response to neurotrophins prefer the gray matter as a more supportive microenvironment (Schwab and Brösamle, 1997).

Biological responses to NGF, including neurite outgrowth and axon elongation, are mediated through binding to two transmembrane receptors. The trkA receptor, of the trk family of receptor tyrosine kinases, is critical for initiating these stereotypical actions of NGF (for review, see Klein, 1994; Green and Kaplan, 1995). The second receptor, the p75 neurotrophin receptor (NTR), may be required to enhance trkA function, especially when NGF is in low concentrations (Barker and Shooter, 1994; Hantzopoulos et al., 1994; Verdi et al., 1994; Lachance et al., 1997). Consistent with this, neurons from the trigeminal and superior cervical ganglia of p $75^{\mathrm{NTR}}$-deficient mice show a shift to 
the right in the NGF dose-response curve (Davies et al., 1993; Lee et al., 1994b), a finding that may explain the perturbed patterns of sensory and sympathetic innervation in p75 mutant mice (Lee et al., 1992, 1994a; Kawaja, 1998). p75 ${ }^{\text {NTR }}$ can also initiate its own signal transduction cascades (Dobrowsky et al., 1994; Carter et al., 1996; Casaccia-Bonnefil et al., 1996), suggesting that $\mathrm{p} 75^{\mathrm{NTR}}$ intracellular signals may converge with those generated by trkA to influence neurotrophin responses.

In a previous examination of transgenic mice overexpressing NGF in astrocytes, we reported that postganglionic sympathetic fibers had invaded the postnatal cerebellum (which had 50-fold higher NGF levels than age-matched cerebella) and that this new growth was confined predominantly to the myelinated tracts (Kawaja and Crutcher, 1997). It is not certain whether this ingrowth of sympathetic axons is impeded by the development and presence of myelin in the cerebellum of adult transgenic mice. Thus, the objective of the present study was to provide a quantitative assessment of this growth of sympathetic axons into the developing cerebellum of NGF transgenic mice. To further clarify the role of $\mathrm{p} 75^{\mathrm{NTR}}$ in NGF-induced sympathetic sprouting, we have also examined the postnatal growth of sympathetic axons into the cerebellum of NGF transgenic mice, which have a targeted deletion of the $\mathrm{p} 75^{\mathrm{NTR}}$ gene.

\section{MATERIALS AND METHODS}

Animals. Three genotypically distinct strains of mice were used in this investigation: (1) NGF/p $75^{+/+}$mice, which overexpress NGF centrally in astrocytes under control of the promoter for glial fibrillary acidic protein (GFAP) and possess two normal alleles for the p $75^{\text {NTR }}$ gene (Kawaja and Crutcher, 1997); (2) NGF/p75 $5^{-1-}$ mice, which overexpress NGF in astrocytes and have a null mutation of $\mathrm{p} 75^{\mathrm{NTR}}$ (Coome et al., 1998); and (3) $\mathrm{C} 57 \mathrm{Bl} / 6$ mice, which are the background strain for both $\mathrm{NGF} / \mathrm{p} 75^{+/+}$ and NGF/p $75^{-1-}$ mice. These two lines of NGF transgenic mice have been bred to homozygosity. Because all littermates carry the NGF transgene, we chose to use the background strain of mice (i.e., C57Bl/6) as control animals. In the generation of this transgenic strain of mice, we have shown that nontransgenic littermates (like $\mathrm{C} 57 \mathrm{Bl} / 6$ mice) display neither elevated levels of NGF in the cerebellum nor an ingrowth of sympathetic axons into this foreign target tissue (Kawaja and Crutcher, 1997). For developmental studies, animals from all three genotypes were killed on postnatal day 14 (P14), P28, P60, and P100. For experimental studies (see below), NGF transgenic lines of mice at P60 and P97 were used, and all were subsequently killed on P100. All animal procedures and surgical protocols were approved by the Queen's University Animal Care Committee.

Surgery. In the first experiment, NGF/p75 ${ }^{+/+}(n=7)$ and NGF/p75 $5^{-/-}$ mice $(n=10)$ at P97 underwent unilateral sympathetic ganglionectomy. Animals were anesthetized with the inhalant Metofane, and under sterile conditions the left superior cervical ganglion (SCG) was surgically excised. After recovering from the anesthesia, animals were assessed for ipsilateral ptosis as confirmation of a successful sympathetic ganglionectomy. Those animals displaying ptosis were allowed to survive for only $3 \mathrm{~d}$ after surgery; thus, this surgical procedure was referred to as an acute ganglionectomy. On the third postoperative day (i.e., at P100), these animals were deeply anesthetized with sodium pentobarbital $(325 \mathrm{mg} / \mathrm{kg}$, i.p.) and killed by transcardial perfusion. In a second experiment, NGF/ p75 $5^{+/+}(n=5)$ and NGF/p75 $5^{-/-}$mice $(n=6)$ at P60 underwent unilateral sympathetic ganglionectomy as described above. Those animals displaying ipsilateral ptosis were allowed to survive for $40 \mathrm{~d}$ after surgery; thus, this surgical procedure was referred to as a chronic ganglionectomy. At P100, these animals were anesthetized with sodium pentobarbital and killed by transcardial perfusion.

Immunohistochemistry. Mice were deeply anesthetized with sodium pentobarbital and then perfused transcardially with a solution of $4 \%$ paraformaldehyde in $0.1 \mathrm{M}$ phosphate buffer, $\mathrm{pH}$ 7.4. The brains were removed, post-fixed for $2 \mathrm{hr}$ in the same fixative, and then immersed for three $\mathrm{d}$ in $30 \%$ phosphate-buffered sucrose. Brains were sectioned coronally using a freezing microtome (40 $\mu \mathrm{m}$ thickness), and sections were stored in cryoprotectant. To ensure that immunostained tissues could be qualitatively and quantitatively compared between age-matched geno- types, all sections were processed under identical conditions, including buffer concentrations, antibody dilutions, temperature, and incubation and reaction times. Free-floating sections of the hindbrain (with both the cerebellum and brainstem) were initially treated in $0.3 \%$ hydrogen per-

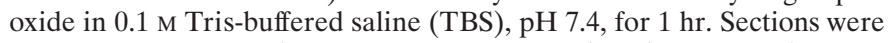
then incubated in $10 \%$ bovine serum albumin (BSA) and $0.25 \%$ Triton $\mathrm{X}-100$ in TBS for $1 \mathrm{hr}$. Endogenous avidin and biotin binding sites were blocked in two successive steps (avidin-biotin blocking kit; Vector Laboratories, Burlingame, CA). The sections were then incubated for 48 $\mathrm{hr}$ at $4^{\circ} \mathrm{C}$ in one of the following primary IgGs: sheep anti-rat tyrosine hydroxylase (TH) IgG (1:1000 dilution; Chemicon, Temecula, CA), rat anti-bovine myelin basic protein (MBP) IgG (1:2000; Chemicon), or rabbit anti-human GFAP IgG (1:1000; Chemicon). Primary antibodies were diluted in a standard solution containing $3 \%$ BSA and $0.25 \%$ Triton $\mathrm{X}-100$ in TBS. All control sections were processed in the absence of primary IgGs. After a rinse in TBS, the sections were incubated for $2 \mathrm{hr}$ at room temperature in the standard solution containing one of the following biotinylated secondary antibodies (Vector Laboratories): rabbit anti-goat $\mathrm{IgG}$ (1:200; for $\mathrm{TH}$ immunoreactivity), rabbit anti-rat IgG (1:500; for MBP immunoreactivity), or goat anti-rabbit $\operatorname{IgG}$ (1:500; for GFAP immunoreactivity). The sections were then rinsed and incubated in avidin-biotin reaction complex (Vector Laboratories) for $2 \mathrm{hr}$ at room temperature and rinsed again. The sections were then reacted with a solution containing $0.05 \%$ diaminobenzidine (DAB) tetrahydrochloride, $0.04 \%$ nickel chloride, and $0.015 \%$ hydrogen peroxide in $0.1 \mathrm{~m}$ TBS. The $\mathrm{DAB}$ reaction was terminated by washing the sections in TBS. After this, sections were mounted on chrome alum-gelatin-coated slides, dehydrated through a graded series of ethanols, and coverslipped. All immunostained sections were viewed and photographed under bright-field optics.

Electron microscopy. At P60, two NGF/p75 ${ }^{+/+}$mice were deeply anesthetized with sodium pentobarbital and perfused with a solution of $4 \%$ paraformaldehyde and $0.1 \%$ glutaraldehyde in $0.1 \mathrm{M}$ phosphate buffer, $\mathrm{pH}$ 7.4. The brains were cut on a vibratome (at $50 \mu \mathrm{m}$ thickness), and sections of cerebellum were stained immunohistochemically for TH (as described for light microscopy), except that there was no hydrogen peroxide pretreatment, nor was Triton X-100 used in the immunostaining. After the DAB reaction, the sections were rinsed and post-fixed in $1 \%$ osmium tetroxide in $0.1 \mathrm{M}$ phosphate buffer, $\mathrm{pH} 7.4$, for $2 \mathrm{hr}$ at room temperature. The sections were rinsed, dehydrated through a graded series of methanols, cleared in propylene oxide, and embedded in a mixture of Araldite and Epon. Ultrathin sections of the cerebellum were cut on a Sorvall Ultramicrotome, and the sections were collected on copper grids, stained with uranyl acetate and lead citrate, and viewed and photographed in a Hitachi 7000 transmission electron microscope.

ELISA. At P100, C57Bl/6 (total $n=3), \mathrm{NGF} / \mathrm{p} 75^{+/+}($total $n=9)$, and $\mathrm{NGF} / \mathrm{p} 75^{-1-}$ (total $n=9$ ) mice were decapitated, and their cerebella were quickly removed for the determination of NGF protein levels. Cerebella were taken from (1) control, nonganglionectomized mice, (2) acutely ganglionectomized mice (i.e., 3 d survival postoperatively), and (3) chronically ganglionectomized mice (i.e., $40 \mathrm{~d}$ survival postoperatively). NGF levels were not measured from ganglionectomized C57Bl/6 mice, because no sympathetic axons are present in the CNS of these animals. The cerebellum of each animal was divided into left (ipsilateral to a ganglionectomy) and right (contralateral to a ganglionectomy) halves, frozen in liquid nitrogen, and stored at $-70^{\circ} \mathrm{C}$. Coded tissue samples were shipped on dry ice to Dr. Crutcher's laboratory (University of Cincinnati Medical Center). Levels of NGF were determined using a modified two-site ELISA that has previously been shown to be both sensitive and specific for NGF (Saffran and Crutcher, 1990; Crutcher et al., 1993). Because the tissues from NGF/p $75^{+/+}$and NGF/p $75^{-1-}$ mice required additional dilutions to obtain accurate values for the very high levels of NGF protein, all tissues assayed were identified only as "transgenic" or "nontransgenic." In some cases, samples had to be run again at higher dilution because of the high levels of NGF in the tissue. The final values were calculated from the total dilution to arrive at a concentration per wet weight of the initial sample. No corrections were made for recovery. Results were tested for significance by a Student's $t$ test.

Quantitation of sympathetic sprouting in cerebellum. Coronal sections of cerebellum stained immunohistochemically for $\mathrm{TH}$ were used to measure the percent area occupied by TH-immunoreactive (TH-IR) axons in the deep white matter (DWM) of C57Bl/6, NGF/p75 $5^{+/+}$, and NGF/p $75^{-/-}$ mice. These measurements of axon density are expected to reflect the degree of collateral growth by sympathetic fibers into the cerebella of transgenic mice. Digitized images of brain sections were captured di- 
rectly from the light microscope with a $40 \times$ objective using a Sony CCD color video camera. The density of TH-IR axons in the cerebellar DWM was quantified using an image analysis software package (Bioquant/ TCW, R \& M Biometrics). Video thresholding, a feature of the software, was used to outline immunoreactive fibers on screen, and the computer determined the area occupied by immunoreactive fibers. Percent area was calculated by dividing the area of TH-IR axons by the area of the DWM being measured. Measurements were taken from two randomly selected regions of the cerebellar DWM per brain section (two sections per animal). For developmental studies, a two-way ANOVA was used to determine whether sympathetic axon density changed with age and differed between genotypes. A Newman-Keuls multiple comparisons post hoc analysis was used to test for differences among ages within each genotype, and a Student's $t$ test was used for comparisons between genotypes at each age. For acutely and chronically ganglionectomized animals, sympathetic axon density was measured in both the ipsilateral and contralateral DWM of all animals (as previously described). A two-way ANOVA was used to determine whether sympathetic axon density in either the ipsilateral or contralateral DWM differed between surgical protocols and differed between genotypes. A post hoc Student's $t$ test was used for comparisons between groups. The data were plotted as mean $\pm \mathrm{SD}$.

Morphometric analysis of the superior cervical ganglia. $\mathrm{C} 57 \mathrm{Bl} / 6(n=4)$, $\mathrm{NGF} / \mathrm{p} 75^{+/+}(n=3)$, and $\mathrm{NGF} / \mathrm{p} 75^{-1-}(n=4)$ mice were deeply anesthetized with sodium pentobarbital and perfused transcardially with a solution of $4 \%$ paraformaldehyde and $1 \%$ glutaraldehyde in $0.1 \mathrm{M}$ phosphate buffer, $\mathrm{pH}$ 7.4. The SCGs were removed, post-fixed for $2 \mathrm{hr}$, and immersed for $2 \mathrm{~d}$ in $30 \%$ phosphate-buffered sucrose. The ganglia were then embedded in OCT (Miles, Elkhart, IN) and frozen in 2-methylbutane at $-20^{\circ} \mathrm{C}$. Serial sections through the entire ganglia were cut on a cryostat at $10 \mu \mathrm{m}$ thickness, thaw-mounted onto chrome alumgelatin-coated slides, stained for Nissl substance with thionin, dehydrated through a graded series of ethanols, cleared, and coverslipped for viewing under bright-field optics. Under observer-blind conditions, all neuronal profiles displaying a prominent nucleolus (or nucleoli) were counted on every fifth section through each ganglion. The sampling frequency (50 $\mu \mathrm{m}$ ) ensures that neurons are not counted twice. Because NGF exposure increases the incidence of split nucleoli in sympathetic neurons (Ruit et al., 1990), total neuron counts were corrected for multiple split nucleoli, according to the calculation of Coggeshall et al. (1984): $N=n \times$ $[N($ c.f. $) / n$ (c.f.)], where $N$ is the true number of sympathetic neurons, $n$ is the number of neurons displaying a prominent nucleolus (or nucleoli), $N($ c.f.) is the number of neurons used to estimate the correction factor, and $n$ (c.f.) is the number of individual nucleolar profiles found in these neurons that constitute $N$ (c.f.). To determine the correction factor $[N($ c.f. $) / n$ (c.f.)], one level from each ganglion was selected, having between 71 and 140 neurons with a nucleolus (or nucleoli). These data were tested for significance using a one-way ANOVA with a post hoc Newman-Keuls test for comparisons between groups. The data were represented as the mean $\pm \mathrm{SD}$.

$m R N A$ expression of trk $A$ within sympathetic neurons. At $\mathrm{P} 60, \mathrm{C} 57 \mathrm{Bl} / 6$ $(n=4), \mathrm{NGF} / \mathrm{p} 75^{+/+}(n=4)$, and NGF/p75 $5^{-1-}(n=4)$ mice were decapitated, and the right and left SCGs (plus attached internal carotid arteries) were isolated and frozen in liquid nitrogen. Trizol (Life Technologies, Gaithersburg, MD) was used to isolate total RNA from the pooled tissues from each genotype. One microgram of total RNA from each genotype was used to synthesize cDNA (Superscript II preamplification system, Life Technologies). To be certain that cDNA synthesis and amplification of gene products from all three genotypes were possible, glyceraldehyde-3-phosphate dehydrogenase (GAPDH; a housekeeping gene product) was first assessed, then trkA. Controls consisted of reactions conducted in either the absence of the reverse transcriptase enzyme or the absence of template. DNAs encoding for GAPDH and trkA were amplified with Taq polymerase using primer-specific sequences for both gene products. For GAPDH, the primer sequences were $5^{\prime}$-GTTGCCATCAATGACCCCTTCATTG-3' ${ }^{\prime}\left(5^{\prime}\right)$ and $5^{\prime}$ GCTTCACCACCTTCTTGATGTCATC-3' $\left(3^{\prime}\right)$. For trkA, the primer sequences were $5^{\prime}$-GGTACCAGCTCTCCAACACTGAGG-3' $\left(5^{\prime}\right)$ and 5'-CCAGAACGTCCAGGTAACTCGGTG-3' (3'). All reactions were conducted under identical conditions (e.g., buffers, temperatures, and times) and underwent 38 cycles. The amplified DNA products were separated in a $0.8 \%$ agarose gel and photographed.

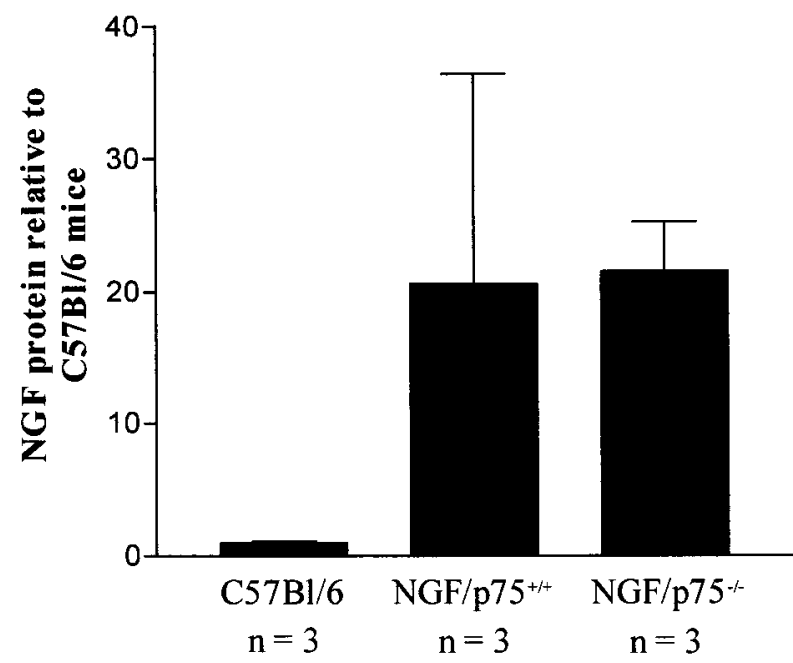

Figure 1. Mean levels of NGF protein in the cerebellum of $\mathrm{C} 57 \mathrm{Bl} / 6$, $\mathrm{NGF} / \mathrm{p} 75^{+/+}$, and NGF/p $75^{-/-}$mice, as measured by a two-site ELISA. The data are represented as fold differences relative to $\mathrm{C} 57 \mathrm{Bl} / 7$ mice, and error bars indicate SD. In contrast to the low levels of NGF protein in the cerebellum of $\mathrm{C} 57 \mathrm{Bl} / 6$ mice, levels of NGF protein are 21- and 22-fold higher in the cerebellum of age-matched NGF/p $75^{+/+}$and NGF/p $75^{-1-}$ mice, respectively. No significant difference in cerebellar NGF levels is detected between NGF/p $75^{+/+}$and NGF/p $75^{-/-}$mice.

\section{RESULTS}

\section{NGF protein in the cerebellum of transgenic mice}

In this study, two lines of GFAP-NGF transgenic mice were used, one of which expresses functional p $75^{\mathrm{NTR}}\left(\mathrm{NGF} / \mathrm{p} 75^{+/+}\right)$and the other of which has a null mutation of the $\mathrm{p} 75^{\mathrm{NTR}}$ gene $\left(\mathrm{NGF} / \mathrm{p} 75^{-/-}\right)$. Both strains of transgenic mice have been shown to express the NGF transgene within the cerebellum as determined by RT-PCR (Kawaja and Crutcher, 1997; Coome et al., 1998). To confirm that these two strains of NGF transgenic mice possessed equal levels of NGF protein, NGF levels in the cerebellum of $\mathrm{C} 57 \mathrm{Bl} / 6, \mathrm{NGF} / \mathrm{p} 75^{+/+}$, and $\mathrm{NGF} / \mathrm{p} 75^{-/-}$mice were measured using a two-site ELISA. In contrast to the low levels of NGF protein found in the cerebellum of $\mathrm{C} 57 \mathrm{Bl} / 6$ mice, the mean levels of NGF protein measured in the cerebellum of $\mathrm{NGF} /$ p $75^{+/+}$and NGF/p75 ${ }^{-/-}$mice were 21- and 22-fold higher, respectively (Fig. 1). No significant difference in the mean levels of NGF protein was detected between the cerebellum of NGF/ p $75^{+/+}$and NGF/p75 ${ }^{-/-}$mice. These data are in agreement with previous results (Coome et al., 1998).

\section{Sympathetic axons invade the cerebellum}

As revealed by $\mathrm{TH}$ immunohistochemistry, the cerebellum of adult (P100) C57Bl/6 mice has a diff use network of fine TH-IR fibers extending throughout the gray and white matter portions (Figs. $2 A, 3 A, B$ ). In the cerebellar DW M, these TH-IR axons are varicose and often observed coursing perpendicular to the intrinsic cerebellar fibers. These TH-IR axons in control C57Bl/6 mice comprise the normal innervation of the cerebellum by neurons of the locus coeruleus, the principal noradrenergic neurons of the CNS.

In agreement with our previous investigation (Kawaja and Crutcher, 1997), the cerebellum of $\mathrm{NGF} / \mathrm{p} 75^{+/+}$mice, at P100, possessed a marked increase in the number of TH-IR axons compared with the cerebellum of $\mathrm{C} 57 \mathrm{Bl} / 6$ mice (Figs. $2 B, 3 C, D$ ). Interestingly, this profusion of new TH-IR axons was localized predominantly to white matter areas of the cerebellum, including 

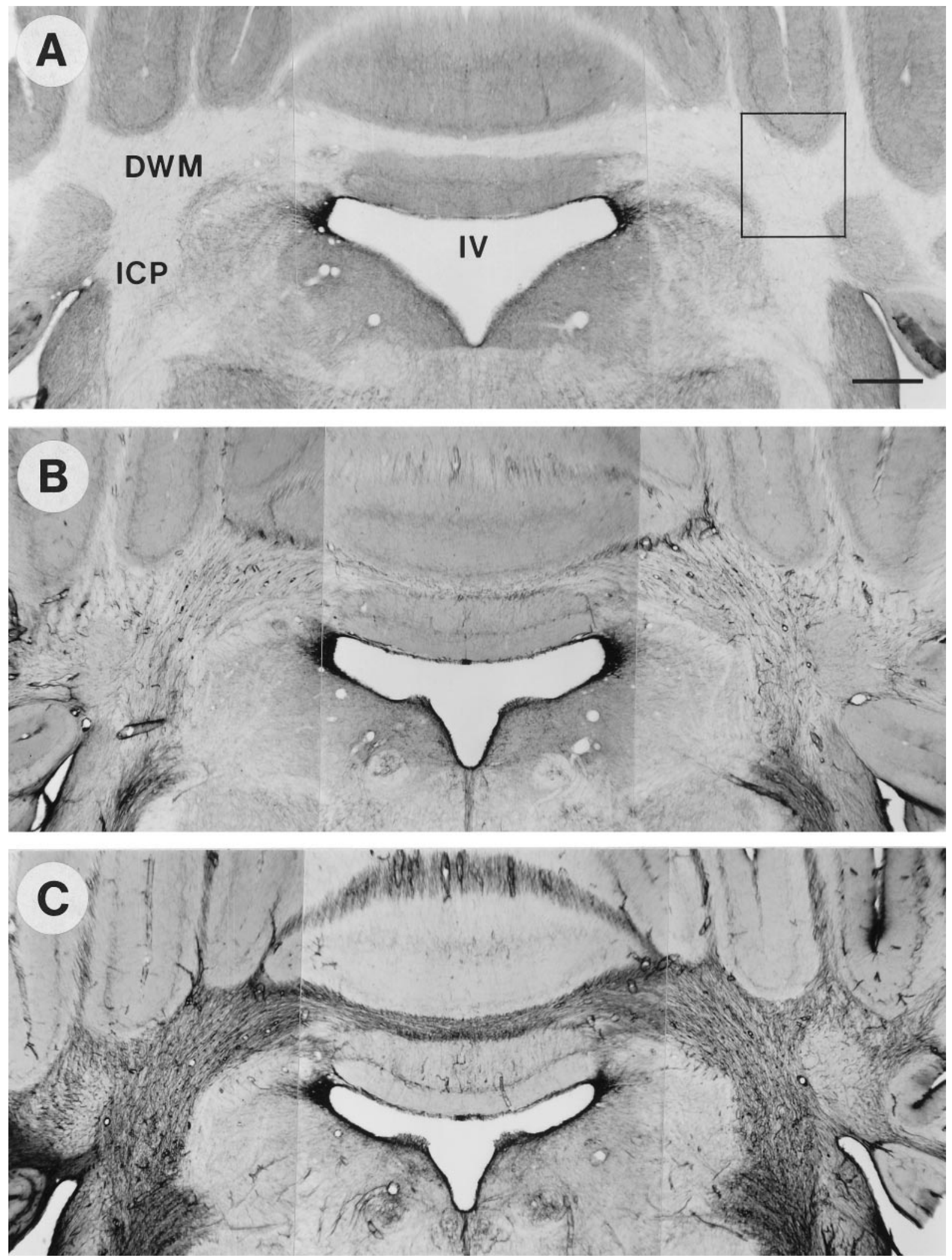

Figure 2. Coronal sections of cerebellum from C57Bl/6, NGF/p $75^{+/+}$, and NGF/p $75^{-/-}$mice at P100, stained immunohistochemically for TH. In C57Bl/6 mice $(A)$, a diffuse network of TH-IR axons is evident in both the cerebellar gray and white matter, representing the local innervation by locus coeruleus neurons. In contrast to these observations, the cerebella of both NGF/p75 $5^{+/+}(B)$ and NGF/p75 $5^{-1-}(C)$ mice display a robust ingrowth of TH-IR axons. These dense plexuses of new TH-IR axons are confined predominantly to the DWM layer and ICPs of the cerebellum and are only occasionally seen extending into the gray matter layers of the cerebellum. Qualitatively, the density of TH-IR axons appears increased in the cerebellum of NGF/p $75^{-1-}$ mice compared with NGF/p $75^{+/+}$mice. The white matter portions of the cerebellum of these mice, as outlined in the box in $A$, are shown at two higher magnifications in Figure 3. Scale bar, $500 \mu \mathrm{m}$. $I V$, Fourth ventricle. 




Figure 3. Higher magnifications of the cerebellar DWM of C57Bl/6, NGF/p75 ${ }^{+/+}$, and NGF/p $75^{-/-}$mice. Note the fine TH-IR locus coeruleus axons, which often course perpendicular to the DWM fibers, in control C57Bl/6 mice $(A, B)$. In contrast, the DWM of both NGF/p75 $5^{+/+}(C$, $D)$ and $\mathrm{NGF} / \mathrm{p} 75^{-1-}(E, F)$ mice display a dramatic increase in TH-IR axons, which course approximately in parallel with the intrinsic DW M fibers. Again note that the density of TH-IR axons appears increased in the DWM of NGF/p $75^{-1-}$ mice relative to NGF/p $75^{+/+}$mice. Scale bars: $A, C, E, 150 \mu \mathrm{m} ; B, D$, $F, 50 \mu \mathrm{m}$.

the DWM, inferior cerebellar peduncle (ICP), and cerebellar folia. These TH-IR axons rarely entered the deep cerebellar nuclei and were only occasionally seen traversing the cerebellar gray matter layers. At high magnification, these TH-IR axons were varicose in nature and coursed mostly parallel to the intrinsic myelinated fibers. There were also perivascular clusters of immunostained axons in the DWM; such arrange- ments were not seen in $\mathrm{P} 100 \mathrm{C} 57 \mathrm{Bl} / 6$ mice. Our previous investigation with $\mathrm{NGF} / \mathrm{p} 75^{+/+}$mice revealed that these new TH-IR axons, which invade the cerebellum, are postganglionic sympathetic fibers, because unilateral removal of the SCG results in a dramatic loss of these axons in the ipsilateral deep white matter (Kawaja and Crutcher, 1997; also see below). The cerebellum of $\mathrm{NGF} / \mathrm{p} 75^{-/-}$mice at P100 also possessed a similar dense plexus 
of new TH-IR sympathetic axons (Figs. 2C, 3E,F). There was, however, a striking increase in the density of TH-IR sympathetic axons in the DWM and ICP of NGF/p $75^{-1-}$ mice compared with age-matched $\mathrm{NGF} / \mathrm{p} 75^{+/+}$mice. There was no obvious increase in TH-IR fibers in the gray matter. Although the reason why sympathetic axons are confined to the white matter and do not extend into the adjacent gray matter remains to be elucidated, possibilities include (1) the presence of inhibitory factors in the gray matter, (2) physical or geometrical constraints of the white matter, and (3) an increased production of transgene NGF in the astrocytes of the white matter relative to those of the gray matter.

In light of the finding that sympathetic axons form a dense plexus within the cerebellum of adult NGF transgenic mice, it was of interest to determine the developmental pattern of sympathetic ingrowth in these animals. We have previously demonstrated that $\mathrm{NGF}$ production in the cerebellum of $\mathrm{NGF} / \mathrm{p} 75^{+/+}$mice begins shortly after the day of birth, increases to 50 -fold higher levels until the end of the second postnatal week, and then slowly decreases to 20-fold higher levels in the adult (Kawaja and Crutcher, 1997) (our unpublished data). This pattern of NGF production parallels the ontogeny of GFAP expression in the rodent CNS (Landry et al., 1990). The percent area occupied by TH-IR axons in the cerebellar DWM of NGF/p $75^{+/+}$and NGF/ $\mathrm{p} 75^{-1-}$ mice was measured at various developmental ages. Statistical analysis of TH-IR axon densities using a two-way ANOVA revealed that there were significant main effects of age $\left(F_{(3,22)}=201.6 ; p<0.001\right)$ and genotype $\left(F_{(1,22)}=22.71 ; p<\right.$ $0.001)$, as well as significant interactions between age and genotype $\left(F_{(3,22)}=5.060 ; p<0.01\right)$.

At P14, TH-IR sympathetic axons were already seen invading the cerebellar DWM (Fig. $4 A$ ). In fact, the percent area occupied by TH-IR axons from the locus coeruleus in the DWM of P100 C57Bl/6 mice was low $(4.1 \pm 0.3 \% ; n=4)$, in comparison with that measured in $\mathrm{P} 14 \mathrm{NGF} / \mathrm{p} 75^{+/+}$mice $(12.8 \pm 2.4 \% ; n=4 ; p<$ 0.001 , Student's $t$ test) (Fig. 5). On examination of THimmunostained sections of the cerebellum from postnatal NGF/ p $75^{+/+}$mice, it appeared as if the density of TH-IR axons in the cerebellar DWM increased with age (compare Figs. 4A, C,E, $3 C$ ). Quantitative analysis confirmed this trend, because the area occupied by TH-IR axons in the DW M at P14 was increased by P28 (46.6 $\pm 1.5 \% ; n=4 ; p<0.001$, Newman-Keuls test), was similar between P28 and P60 (mean value, 45.9\%; $n=2$ ), and was increased again between P28 and P100 (65.8 $\pm 4.3 \% ; n=4 ; p<$ 0.001) (Fig. 5). These findings demonstrate that TH-IR sympathetic axons begin their growth into the cerebellum of $\mathrm{NGF} /$ p $75^{+/+}$mice shortly before P14 and continue to increase in density into adulthood.

Analysis of $\mathrm{NGF} / \mathrm{p} 75^{-/-}$mice revealed that, similar to $\mathrm{NGF} /$ p $75^{+/+}$mice, TH-IR sympathetic axons are evident in the DWM by P14, and the density of these TH-IR axons increases throughout the life of the animals (compare Figs. 4B,D,F, $3 E$ ). The percent area occupied by TH-IR axons in the cerebellar DWM of $\mathrm{NGF} / \mathrm{p} 75^{-1-}$ mice increased dramatically between P14 and P28 $(26.6 \pm 4.4$ vs $46.4 \pm 6.4 \% ; n=4$ for each; $p<0.001$, NewmanKeuls test), was similar between P28 and P60 (49.7 $\pm 4.1 \% ; n=$ $3 ; p<0.05)$, and was increased again between P60 and P100 (80.1 $\pm 5.9 \% ; n=5 ; p<0.001)$ (Fig. 5). Remarkably, the density of TH-IR axons in the DWM of NGF/p75 $15^{-1-}$ mice was greater than that measured in NGF/p $75^{+/+}$mice at both P14 and P100 $(p<0.01$, Student's $t$ test). Both lines of mice displayed similar densities of TH-IR axons at P28 ( $p=0.9894$, Student's $t$ test), and no statistical comparison could be made for P60. Taken together, our data provide evidence that sympathetic axons, in the absence of $\mathrm{p} 75^{\mathrm{NTR}}$, are capable of enhanced growth within the NGF-rich cerebellum of transgenic mice during postnatal development and into adulthood.

\section{Axon growth occurs in myelinated portions of the cerebellum}

One of the remarkable features of sympathetic growth into the cerebellum of postnatal and adult transgenic mice is the topographical distribution of these aberrant fibers. In both $\mathrm{NGF} /$ p $75^{+/+}$and NGF/p $75^{-/-}$mice, the majority of TH-IR sympathetic axons remains confined to the DWM and ICP, with few fibers extending into the adjacent gray matter layers. In agreement with other investigations (Foran and Peterson, 1992; Hamano et al., 1996), we were able to detect MBP, a major constituent of central myelin, in the DWM and ICP of the cerebellum using immunohistochemistry. As early as the second week of postnatal life, a comparable intensity of MBP immunostaining was seen in both $\mathrm{NGF} / \mathrm{p} 75^{+/+}$and NGF/p $75^{-/-}$mice (data not shown). This strong immunoreactivity was equally evident in the myelinated portions of the cerebellum of P100 NGF/p $75^{+/+}$and $\mathrm{NGF} / \mathrm{p} 75^{-/-}$mice. The staining intensity for $\mathrm{MBP}$ in both lines of NGF transgenic mice was comparable with that seen in the cerebellum of control $\mathrm{C} 57 \mathrm{Bl} / 6$ mice. These data reveal that the collateral growth of TH-IR sympathetic axons into the cerebella of postnatal NGF/p $75^{+/+}$and $\mathrm{NGF} / \mathrm{p} 75^{-/-}$mice continues into adulthood, despite the presence of central myelin within the DWM and ICP.

To assess which cellular substrates were used by these TH-IR sympathetic axons, we examined the localization of TH immunoreactivity at the ultrastructural level in P100 NGF/p75 ${ }^{+/+}$mice. Small clusters of unmyelinated axons, some of which had immunoreactivity for $\mathrm{TH}$, were found among the larger myelinated fibers of the cerebellar DWM (Fig. 6). The absence of a glial ensheathment of these unmyelinated TH-IR axons indicates that Schwann cells do not migrate along with the sympathetic axons invading the cerebellum. Rather, these TH-IR unmyelinated axons were seen immediately apposed to nonimmunoreactive unmyelinated axons and myelinated axons alike. Although it is uncertain whether these sympathetic fibers use intrinsic myelinated axons as substrates for growth, it is evident that these peripheral fibers are capable of continued growth within myelinated portions of the adult CNS.

\section{Topography of sympathetic axons within the cerebellar DWM}

To assess the extent to which sympathetic axons arising from the right SCG invade both halves of the cerebellum, NGF/p75 and $\mathrm{NGF} / \mathrm{p} 75^{-1-}$ mice underwent unilateral removal of the left SCG 3 d before P100. This procedure allowed visualization of only those sympathetic axons arising from the right SCG in both the ipsilateral and contralateral DWM. After acute ganglionectomy in $\mathrm{NGF} / \mathrm{p} 75^{+/+}$mice, the bulk of TH-IR sympathetic axons from the contralateral SCG did not extend past the cerebellar midline (Fig. 7A). In contrast, unilateral SCG removal in NGF/ p75 ${ }^{-1-}$ mice revealed that many TH-IR sympathetic axons of the contralateral SCG extended up to and beyond the cerebellar midline, some of which continued into the upper portion of the ipsilateral DWM (Fig. 7B).

We next made a detailed examination of sympathetic fiber density in the ipsilateral and contralateral DWM of animals that had undergone either an acute ganglionectomy or a chronic 

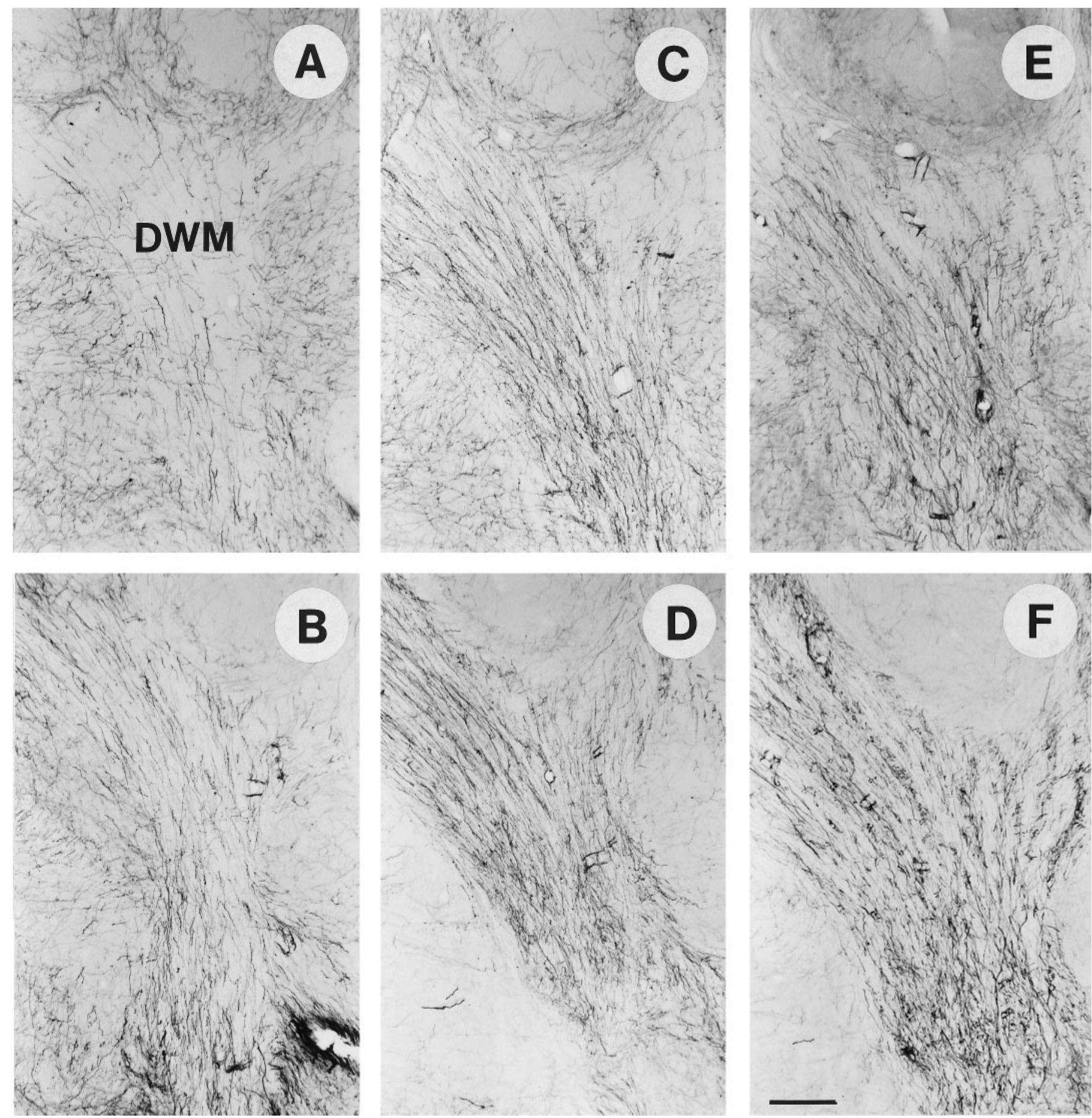

Figure 4. Coronal sections of cerebellum from NGF/p75 ${ }^{+/+}$(top row) and NGF/p75 $5^{-/}$(bottom row) mice at P14 (A, B), $\mathrm{P} 28(C, D)$, and $\mathrm{P} 60(E, F)$, stained immunohistochemically for TH. TH-IR sympathetic axons are already observed growing into the cerebellar DWM by P14 in both NGF/p75 ${ }^{+/+}$ and NGF/p $75^{-1-}$ mice. In both NGF transgenic lines of mice, the density of TH-IR axons in the cerebellar DWM appears to increase with age. It is also apparent that the density of TH-IR axons is greater in the DWM of NGF/p $75^{-/-}$mice compared with NGF/p $75^{+/+}$mice. Scale bar, $150 \mu \mathrm{m}$.

ganglionectomy. This was done to determine (1) the degree to which sympathetic axons of the contralateral SCG extend into the ipsilateral DWM and (2) whether this unilateral sympathetic "denervation" of the cerebellum is followed by collateral sprouting from the intact contralateral fibers. Quantitation of sympathetic fiber density is shown in Figure 8. For all animals, with either an acute or chronic ganglionectomy, the percent area occupied by TH-IR axons was dramatically reduced in the ipsi- lateral DWM compared with the contralateral DWM of the same animal ( $p<0.001$, Student's $t$ test). Regardless of acute or chronic ganglionectomy, the percent area occupied by TH-IR axons in the contralateral (intact) DWM was higher in NGF/ $\mathrm{p} 75^{-/-}$mice relative to $\mathrm{NGF} / \mathrm{p} 75^{+/+}$mice $(p<0.001$, two-way ANOVA; $\left.F_{(1,24)}=148.6\right)$, consistent with our observations of sympathetic axon density in nonganglionectomized animals. Moreover, sympathetic axon density in the contralateral DWM 


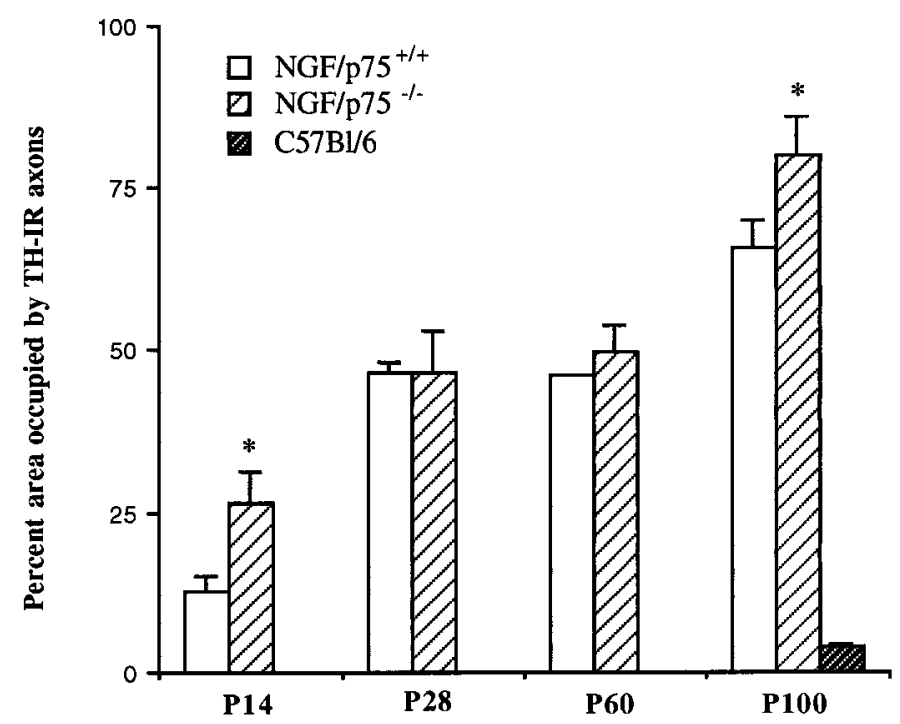

Figure 5. Quantitation of TH-IR axon density in the cerebellar DWM of $\mathrm{C} 57 \mathrm{Bl} / 6, \mathrm{NGF} / \mathrm{p} 75^{+/+}$, and $\mathrm{NGF} / \mathrm{p} 75^{-/-}$mice at developmental time points. There are significant increases in the percent area occupied by TH-IR axons in the DWM of NGF/p $75^{-/-}$mice relative to NGF/p $75^{+/+}$ mice at both $\mathrm{P} 14$ and $\mathrm{P} 100\left({ }^{*} p<0.001\right)$. The density of TH-IR axons is lowest in the DWM of P100 C57Bl/6 mice.

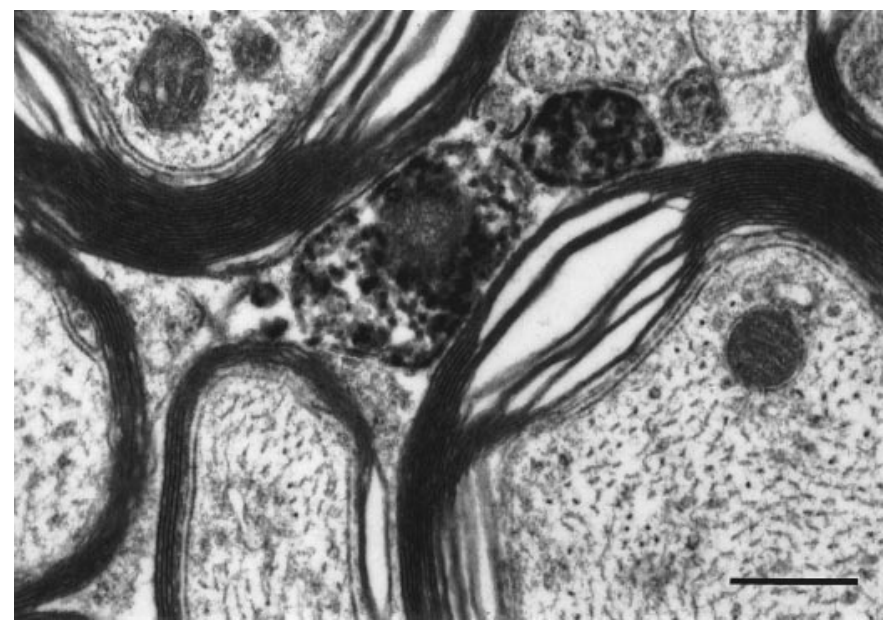

Figure 6. Electron photomicrograph showing the localization of $\mathrm{TH}$ immunoreactivity in the cerebellar deep white matter of adult NGF/ p $75^{+/+}$mice. TH-IR unmyelinated axons are seen coursing among myelinated fibers of the cerebellum, often as part of a small cluster of unmyelinated axons. TH-IR unmyelinated axons lack any glial support and are often observed in close apposition to the surface of myelinated axons and unmyelinated axons alike. Scale bar, $0.5 \mu \mathrm{m}$.

did not differ between acute and chronic ganglionectomy in either of the NGF transgenic strains. Examination of the ipsilateral DWM revealed that the density of sympathetic fibers was again higher in $\mathrm{NGF} / \mathrm{p} 75^{-/-}$mice relative to $\mathrm{NGF} / \mathrm{p} 75^{+/+}$mice $(p<$ 0.001 , two-way ANOVA; $\left.F_{(1,24)}=37.82\right)$, regardless of the type of ganglionectomy. The finding that a small number of TH-IR axons persisted in the ipsilateral DWM after acute ganglionectomy suggests that a minor proportion of contralateral (intact) SCG axons normally project past the cerebellar midline and into the ipsilateral DWM of both NGF transgenic strains. This proportion, however, is greater in $\mathrm{NGF} / \mathrm{p} 75^{-1-}$ mice. Our data also indicate that the effect of chronic ganglionectomy was not the same for $\mathrm{NGF} / \mathrm{p} 75^{+/+}$and $\mathrm{NGF} / \mathrm{p} 75^{-/-}$mice. Whereas no significant change in sympathetic fiber density was observed in the ipsilateral DWM of $\mathrm{NGF} / \mathrm{p} 75^{+/+}$mice between acute and chronic ganglionectomy, sympathetic fiber density in the ipsilateral DWM of $\mathrm{NGF} / \mathrm{p} 75^{-1-}$ mice was increased after chronic ganglionectomy compared with acute ganglionectomy $(p<0.01$, two-way ANOVA; $\left.F_{(1,24)}=9.185\right)$. These findings suggest that unilateral removal of the SCG results in the collateral sprouting of sympathetic axons of the contralateral (intact) SCG within the myelinated portions of the adult cerebellum in $\mathrm{NGF} / \mathrm{p} 75^{-1-}$ mice but not $\mathrm{NGF} / \mathrm{p} 75^{+/+}$mice.

\section{Levels of NGF protein and reactive cerebellar astrocytes}

Could the collateral sprouting of sympathetic axons observed in the ipsilateral DWM of chronically ganglionectomized NGF/ p75 $1-$ mice be attributed to a selective upregulation of NGF protein in the cerebella of $\mathrm{NGF} / \mathrm{p} 75^{-/-}$mice only? To address this possibility, NGF levels were measured in the ipsilateral and contralateral halves of the cerebellum of $\mathrm{NGF} / \mathrm{p} 75^{+/+}$and $\mathrm{NGF} /$ p75 ${ }^{-1-}$ mice 3 and $40 \mathrm{~d}$ after unilateral sympathetic ganglionectomy. For each animal, the level of NGF protein in the ipsilateral cerebellum was plotted as the fold difference of NGF levels measured in the contralateral half of the same animal (Fig. 9). In $\mathrm{NGF} / \mathrm{p} 75^{+/+}$mice, the mean levels of NGF protein in the ipsilateral cerebellum were increased relative to the contralateral cerebellum both 3 and $40 \mathrm{~d}$ after ganglionectomy, but these increases were not statistically significant. In contrast, the mean level of NGF protein in the ipsilateral cerebellum of NGF/p $75^{-/-}$ mice $3 \mathrm{~d}$ after ganglionectomy was dramatically increased above that measured in the contralateral cerebellum $(p<0.001$, Student's $t$ test). This upregulation in NGF protein in the ipsilateral cerebellum appeared to be short-lived, because at $40 \mathrm{~d}$ after ganglionectomy, the mean level of NGF protein in the ipsilateral cerebellum was again not statistically different from that measured in the contralateral cerebellum of NGF/p $75^{-/-}$mice.

What could account for this marked increase in NGF protein ipsilateral to the SCG removal in acutely ganglionectomized $\mathrm{NGF} / \mathrm{p} 75^{-/-}$mice? Because the NGF transgene is driven by the promoter for GFAP, we examined sections of cerebella stained immunohistochemically for GFAP. Cerebellar sections from nonganglionectomized $\mathrm{C} 57 \mathrm{Bl} / 6, \mathrm{NGF} / \mathrm{p} 75^{+/+}$, and $\mathrm{NGF} / \mathrm{p} 75^{-1-}$ mice all possessed numerous GFAP-positive astrocytes in the cerebellar DWM but fewer in the adjacent gray matter layers. The staining intensity of GFAP immunoreactivity appeared homogeneous throughout these structures and comparable among genotypes (data not shown). In chronically ganglionectomized $\mathrm{NGF} / \mathrm{p} 75^{+/+}$and $\mathrm{NGF} / \mathrm{p} 75^{-1-}$ mice, as well as acutely ganglionectomized NGF/p $75^{+/+}$mice, a modest increase in GFAP immunostaining was evident in the cerebellar white and gray matter areas ipsilateral to the SCG removal. The ipsilateral cerebellum of acutely ganglionectomized NGF/p $75^{-/-}$mice, however, displayed the greatest increase in GFAP immunostaining, which was evident in astrocytes of both cerebellar white and gray matter areas. These observations provide an anatomical correlate of the increased transgene production of NGF in these animals only. We speculate that a greater gliotic reaction (which includes GFAP upregulation) is triggered in the cerebella of NGF/p75 ${ }^{-1-}$ mice by the degeneration of relatively more sympathetic fibers and, hence, upregulation of the NGF transgene. Taken together, our data indicate that, at least in $\mathrm{NGF} / \mathrm{p} 75^{-1-}$ mice, collateral sprouting of intact (contralateral) sympathetic axons within my- 

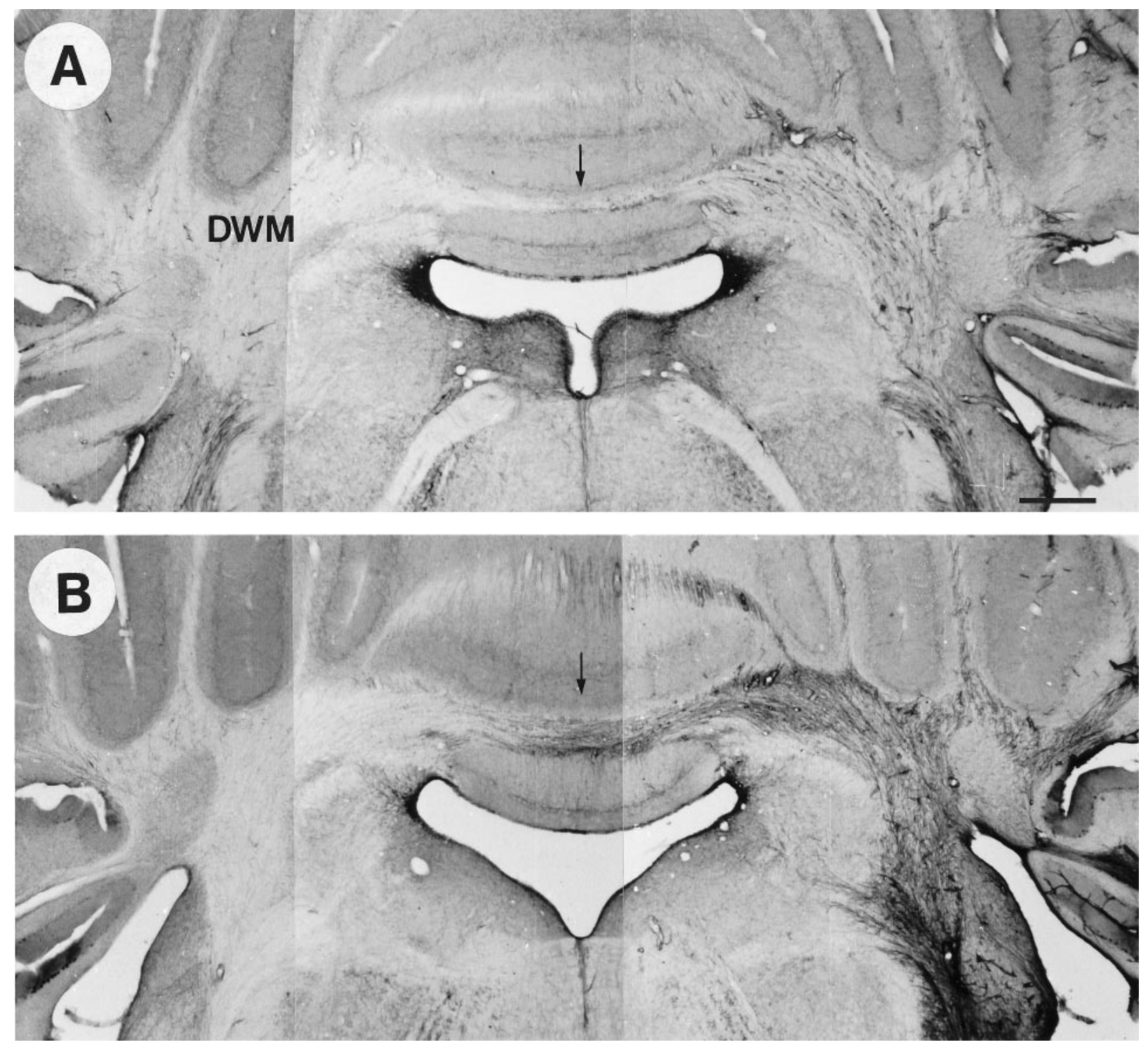

Figure 7. Coronal sections of cerebellum from acutely ganglionectomized NGF/p $75^{+/+}$and NGF/p $75^{-/-}$mice, stained immunohistochemically for TH. The unilateral removal of the SCG allows visualization of those sympathetic fibers from the contralateral ganglion. In NGF/p75 ${ }^{+/+}$mice $(A)$, few TH-IR axons from the contralateral SCG extend as far as the cerebellar midline (arrow). In contrast, numerous contralateral sympathetic axons in NGF/p75 ${ }^{-/}$ mice $(B)$ extend past the cerebellar midline (arrow) and into the upper portions of the ipsilateral DWM. Scale bar, $500 \mu \mathrm{m}$.

elinated portions of the mature CNS can occur and is likely stimulated by a short-lived upregulation of NGF protein. Because ganglionectomy failed to cause an upregulation of NGF protein in $\mathrm{NGF} / \mathrm{p} 75^{+/+}$mice, we cannot exclude the possibility that sympathetic axons are capable of collateral sprouting in the CNS of these mice.

\section{Sympathetic neuron number}

To exclude the possibility that this increased sympathetic sprouting into the cerebellum was directly linked to increased sympathetic neuron survival in $\mathrm{NGF} / \mathrm{p} 75^{-1-}$ mice, we determined the numbers of SCG neurons in adult animals. Specifically, the SCGs from $\mathrm{C} 57 \mathrm{Bl} / 6, \mathrm{NGF} / \mathrm{p} 75^{+/+}$, and $\mathrm{NGF} / \mathrm{p} 75^{-/-}$mice were serially sectioned at $10 \mu \mathrm{m}$, and the number of neurons with a prominent nucleolus (or nucleoli) were counted on every fifth section. Exposure to high levels of NGF is known to increase the incidence of multiple nucleoli among postganglionic sympathetic neurons (Ruit et al., 1990). Qualitative assessment of the SCG revealed more sympathetic neurons with two to four nucleolar fragments in $\mathrm{NGF} / \mathrm{p} 75^{+/+}$and $\mathrm{NGF} / \mathrm{p} 75^{-/-}$mice than in $\mathrm{C} 57 \mathrm{Bl} / 6$ mice (Fig. 10A). Quantitation of the incidence of multiple nucleoli confirmed a significant increase in the ratio of total nucleoli to SCG neurons counted among NGF/p75 ${ }^{+/+}$mice $(2.95 \pm 0.13)$ and $\mathrm{NGF} / \mathrm{p} 75^{-1-}$ mice $(2.97 \pm 0.12)$ relative to $\mathrm{C} 57 \mathrm{Bl} / 6$ mice $(2.28 \pm 0.06)$. In light of these observations, the total SCG neuron counts were corrected for the presence of multiple nucleoli, according to the method of Coggeshall et al. (1984). This analysis demonstrated a statistically significant increase in the numbers of sympathetic neurons of both NGF/p $75^{+/+}$mice $(1789 \pm 32 ; n=$ $3)$ and NGF/p $75^{-1-}$ mice $(2045 \pm 338 ; n=4)$ relative to control C57Bl $/ 6$ mice (1112 $\pm 168 ; n=4 ; p<0.05$, Newman-Keuls test) (Fig. $10 B$ ). No statistically significant difference in the number of SCG neurons was detected between $\mathrm{NGF} / \mathrm{p} 75^{+/+}$and $\mathrm{NGF} /$ p75 ${ }^{-1-}$ mice. Thus, these finding indicate that the enhanced sprouting of sympathetic axons in the cerebellum in NGF/p75 


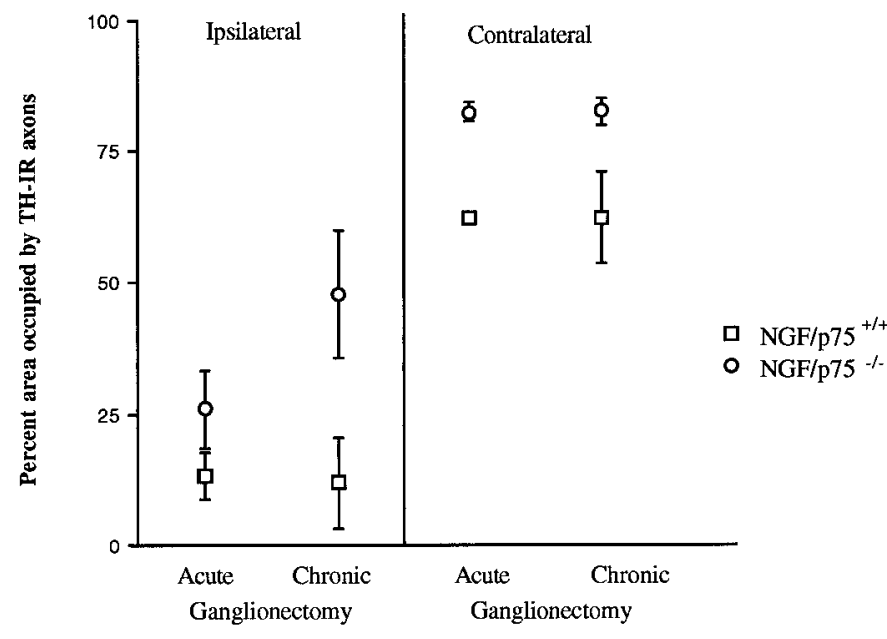

Figure 8. Quantitation of sympathetic axon density in the ipsilateral and contralateral DWM of both lines of transgenic mice after acute and chronic ganglionectomy. Data for NGF/p $75^{+/+}$mice $(n=7$ acute and 5 chronic ganglionectomized animals) are represented by boxes, and data for NGF/p $75^{-1-}$ mice $(n=10$ acute and 6 chronic ganglionectomized animals) are represented by circles. In all acutely and chronically ganglionectomized animals, there is a significant decrease in the percent area occupied by TH-IR axons in the ipsilateral DWM relative to the contralateral DWM within the same experimental group $(p<0.001)$. In the contralateral DWM, the density of sympathetic axons is higher in NGF/ $\mathrm{p} 75^{-1-}$ mice relative to NGF/p $75^{+/+}$mice $(p<0.001)$, and these densities are not affected by chronic ganglionectomy. Note that the density of sympathetic axons that persist in the ipsilateral DWM, after either acute and chronic ganglionectomy, is also higher in NGF/p $75^{-1-}$ mice relative to $\mathrm{NGF} / \mathrm{p} 75^{+/+}$mice $(p<0.001)$. Importantly, sympathetic fiber density increases in the ipsilateral DWM between acutely and chronically ganglionectomized NGF/p $75^{-1-}$ mice but not between acutely and chronically ganglionectomized NGF/p $75^{+/+}$mice $(p<0.01)$. All data are represented as mean $\pm \mathrm{SD}$.

mice is not a reflection of increased survival of sympathetic neurons compared with $\mathrm{NGF} / \mathrm{p} 75^{+/+}$mice.

\section{trkA expression among sympathetic neurons}

To exclude the possibility that differences in the degree of sympathetic sprouting were attributable to a perturbed expression for trkA mRNA, we used RT-PCR to ensure continued mRNA expression for trkA in sympathetic neurons of the SCG (Fig. $10 C)$. All three genotypes had detectable levels of the DNA products for trkA (and GAPDH), thereby revealing that the absence of $\mathrm{p} 75^{\mathrm{NTR}}$ expression did not affect the detection of trkA mRNA from the SCG of NGF/p75 ${ }^{-/-}$mice; these data provide only a qualitative assessment of the presence or absence of mRNA expression.

\section{DISCUSSION}

In the present study, elevated levels of NGF protein in the developing CNS of transgenic mice coincides with the growth of sympathetic axons into the deep white matter portions of the cerebellum during the period of myelination. Despite the presence of central myelin, sympathetic axons continue to grow and increase in density within the cerebellar DWM as the animals mature into adulthood. Surprisingly, the growth of sympathetic axons within the myelinated portions of the NGF-rich cerebellum was greater in NGF transgenic mice lacking expression of the $\mathrm{p} 75^{\mathrm{NTR}}$.

\section{Axon growth within myelinated structures}

It is generally accepted that the adult mammalian CNS is unable to support axon growth over long distances. One of the factors

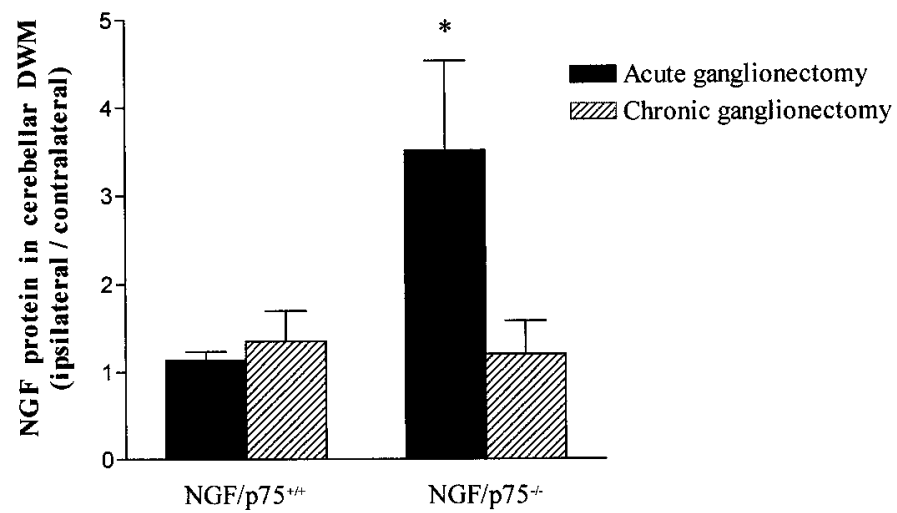

Figure 9. Levels of NGF protein in the cerebellum of acutely and chronically ganglionectomized NGF/p $75^{+/+}$and NGF/p $75^{-/-}$mice $(n=$ 3 animals per experimental group), as measured by a two-site ELISA. Levels of NGF in the ipsilateral half of the cerebellum are presented as fold differences relative to the contralateral half from the same animal, and error bars indicate SD. This analysis reveals a significant increase in NGF levels only within the ipsilateral cerebellum of NGF/p $75^{-1-}$ mice after acute ganglionectomy $\left({ }^{*} p<0.001\right)$. In all other cases, no significant differences in NGF levels are detected between ipsilateral and contralateral cerebellar halves.

influencing the limited growth of axons is the presence of active growth-inhibitory factors associated with oligodendrocytes and CNS myelin (Caroni and Schwab, 1988a,b; Schwab and Caroni, 1988; Crutcher, 1989; Savio and Schwab, 1990; for review, see Schwab et al., 1993). In support of this notion, neutralization of the inhibitory properties of central myelin allows both the regeneration and collateral sprouting of corticospinal fibers (Savio and Schwab, 1990; Schnell and Schwab, 1990; Bregman et al., 1995; Vanek et al., 1998). Another factor that may contribute to the loss of plasticity in the CNS is the lack of appropriate growthpromoting molecules (Schwartz et al., 1989). Menesini-Chen et al. (1978) were the first to show that neurotrophins could promote axon growth within the mammalian CNS. Infusions of NGF into the brainstem of neonatal rats resulted in the ingrowth of sympathetic axons within yet-to-be myelinated tracts of the CNS (Menesini-Chen et al., 1978). However, similar inf usions of NGF into the brainstem of adult animals failed to elicit such ingrowth. Since this time, a number of studies have demonstrated that local application of neurotrophins can enhance sprouting responses of various CNS axons (Schnell et al., 1994; Tuszynski et al., 1994; Xu et al., 1995; Sawai et al., 1996; Bregman et al., 1997; Grill et al., 1997; Schwab and Brösamle, 1997; Ye and Houle, 1997). In these experimental paradigms, however, neurotrophin-induced axon sprouting remains primarily confined to peripheral nerve grafts, transplants, and nonmyelinated portions of the mature CNS. Our observation that NGF overexpression in the cerebellum of postnatal transgenic mice elicits the growth of sympathetic axons into the cerebellar white matter complements the findings of Menesini-Chen et al. (1978). Our data further reveal that if NGF levels remain elevated in the CNS as the animals mature, the growth of sympathetic axons within myelinated tracts continues unabated into adulthood. Importantly, Davies et al. (1997) recently showed that adult neurons implanted into the adult CNS white matter are capable of long-distance axonal growth. Using a microtransplantation technique that minimizes glial scar formation, these authors demonstrated that grafted neurons are capable of rapid and extensive growth of new axons through this myelinated environment. Taken together, our study and that of Davies 

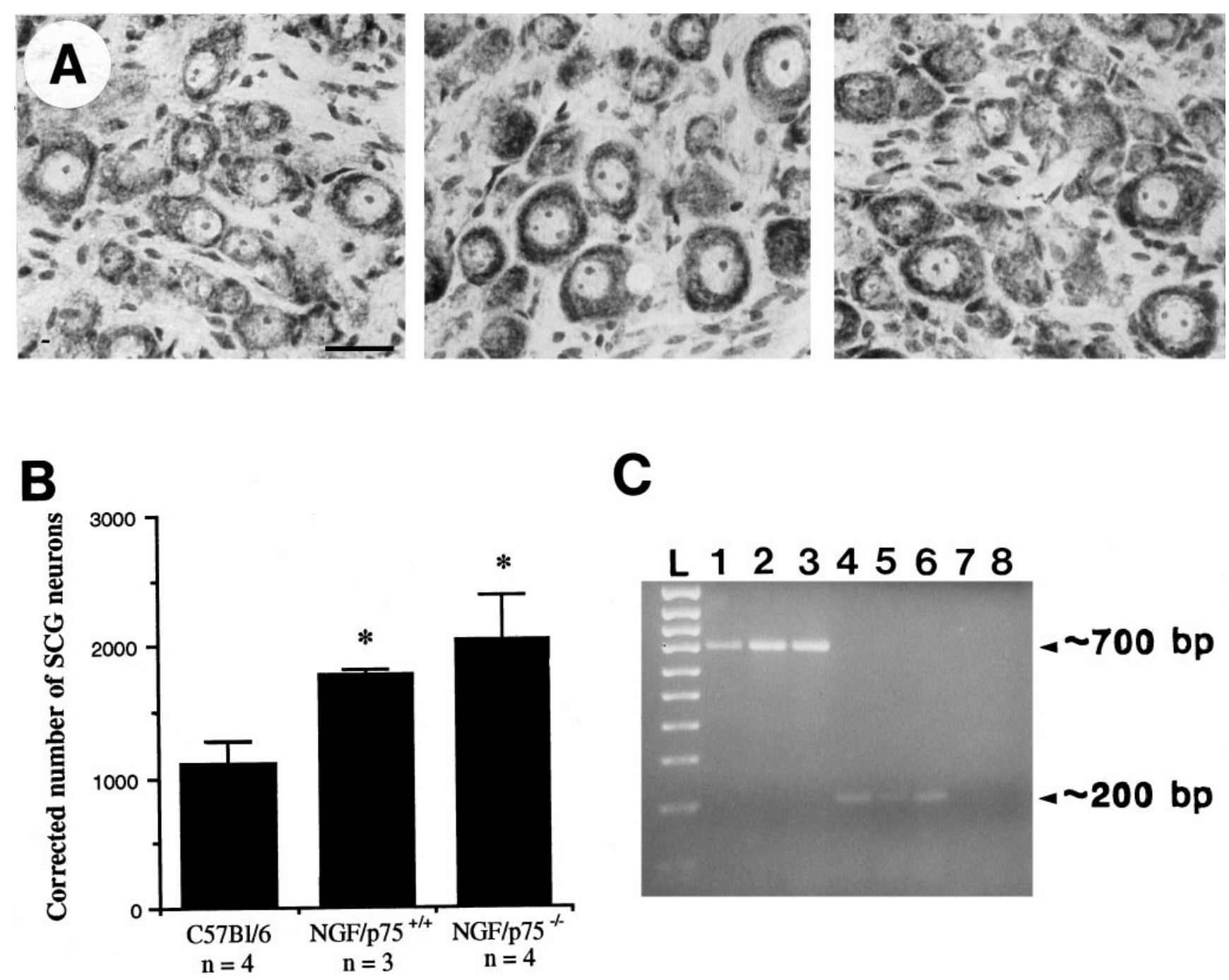

Figure 10. Morphological and neurochemical characteristics of SCG from P60 C57Bl/6, NGF/p75 ${ }^{+/+}$, and NGF/p75 ${ }^{-/-}$mice. A, Nissl-stained sections of SCG from C57Bl/6 (left), NGF/p75 ${ }^{+1+}$ (center), and NGF/p75 $5^{-1-}$ (right) mice reveal a greater incidence of multiple nucleoli among somata of both NGF transgenic lines of mice. $B$, Counts of neuronal profiles in SCG of adult animals show a significant increase in the number of SCG neurons in both $\mathrm{NGF} / \mathrm{p} 75^{+1+}$ and NGF/p75 $5^{-1-}$ mice compared with $\mathrm{C} 57 \mathrm{Bl} / 6$ mice $\left({ }^{*} p<0.05\right)$. No significant difference was detected in the number of SCG neurons between NGF/p75 $5^{+/+}$and NGF/p75 ${ }^{-1-}$ mice. $C$, RT-PCR amplification of GAPDH and trkA in SCG taken from P60 C57Bl/6, NGF/p75 ${ }^{+/+}$, and $\mathrm{NGF} / \mathrm{p} 75^{-1-}$ mice. GAPDH cDNA product $(\sim 700 \mathrm{bp})$ is detectable in SCG from C57Bl/6 (lane 1), NGF/p75 ${ }^{+/+}$(lane 2), and NGF/p75 ${ }^{-1-}$ (lane 3 ) mice. Likewise, trkA cDNA product ( $\sim 200 \mathrm{bp}$ ) is detectable in SCG from C57Bl/6 (lane 4), NGF/p75 ${ }^{+/+}$(lane 5), and NGF/p75 ${ }^{-/-}$(lane 6 ) mice. No trkA cDNA product is detectable in the absence of RNA template (lane 7), and GAPDH cDNA product is not detectable in the absence of the reverse transcriptase enzyme (lane 8). L, 100 bp ladder.

et al. (1997) provide evidence supporting the notion that axonal growth in myelinated portions of the adult CNS is possible, provided that there is an adequate supply of the appropriate neurotrophin.

An important issue is how sympathetic axons are able to increase in density in the cerebellar DWM of NGF transgenic mice throughout life, despite the presence of central myelin. At the ultrastructural level, TH-IR axons are observed coursing through the cerebellar white matter as part of a small cluster of unmyelinated axons. Thus, although TH-IR unmyelinated axons are seen in contact with intrinsic myelinated fibers, they are also in close apposition to other unmyelinated axons. Our previous work with $\mathrm{NGF} / \mathrm{p} 75^{+/+}$and NGF/p $75^{-1-}$ mice has demonstrated that unmyelinated sensory axons, immunoreactive for the neuropeptide calcitonin gene-related peptide, also invade the cerebellar DWM by the second postnatal week (Kawaja et al., 1997;
Coome et al., 1998). Moreover, in both lines of NGF transgenic mice, these sensory axons are immunoreactive for the glycoprotein L1 (Walsh et al., 1998), a cell adhesion molecule that plays an important role in promoting axon fasciculation (Fischer et al., 1986). On the basis of these findings, we propose that sympathetic axons are capable of continued growth within a myelinated environment by using other unmyelinated axons as a substrate for growth. Such a postulate would predict that the expression of cell surface molecules that promote axon-axon fasciculation, such as L1, would be extremely important in allowing neurotrophin-induced growth within myelinated environments of the mature CNS.

\section{Role of the $\mathrm{p} 75^{\mathrm{NTR}}$ in the growth of sympathetic axons}

In the present study, we also used a hybrid line of mice, which overexpresses NGF in astrocytes and has a null mutation in 
$\mathrm{p} 75^{\mathrm{NTR}}$ (NGF/p75 ${ }^{-1-}$ mice), to further clarify the role of $\mathrm{p} 75^{\mathrm{NTR}}$ in neurotrophin-induced axon growth responses. Sympathetic axons invade the myelinated cerebellar tracts of $\mathrm{NGF} /$ p $75^{+/+}$and NGF/p $75^{-/-}$mice alike, both of which display comparable levels of NGF protein. The most striking observation in $\mathrm{NGF} / \mathrm{p} 75^{-/-}$mice is that the magnitude of the growth response by sympathetic axons within the cerebellum is greater than that of NGF transgenic mice expressing functional p $75^{\mathrm{NTR}}$. More specifically, the density of sympathetic axons within the cerebellar DWM is increased, and sympathetic axons extend further into the cerebellum of $\mathrm{NGF} / \mathrm{p} 75^{-/-}$mice compared with $\mathrm{NGF} /$ p $75^{+/+}$mice.

How might the presence of $\mathrm{p} 75^{\mathrm{NTR}}$ limit the growth of sympathetic axons in an NGF-rich target? Because p $75^{\text {NTR }}$ is not expressed by glial cells in the cerebellar DWM, attenuation of axon growth must be a consequence of the presence of $\mathrm{p} 75^{\mathrm{NTR}}$ on sympathetic terminals. The levels of p $75^{\mathrm{NTR}}$ and trkA in sympathetic neurons usually exist in a ratio of $\sim 10: 1$ (Chao and Hempstead, 1995), despite the fact that the trkA receptor is necessary for stereotypical NGF responses, including neurite outgrowth (Loeb et al., 1991; Loeb and Greene, 1993). Moreover, sympathetic neurons undergoing collateral sprouting, in response to terminally derived $\mathrm{NGF}$, upregulate only their expression of p75 ${ }^{\text {NTR }}$ and not trkA (Miller et al., 1994). Consistent with this, sympathetic neurons of the $\mathrm{NGF} / \mathrm{p} 75^{+/+}$mice have increased levels of expression for $\mathrm{p} 75^{\mathrm{NTR}}$ but not trkA (Coome and Kawaja, 1999). It has been suggested that a selective upregulation in $\mathrm{p} 75^{\mathrm{NTR}}$ may represent an inhibitory feedback loop, whereby the presence of more $\mathrm{p} 75^{\mathrm{NTR}}$ at terminal axons sequesters NGF away from the high-affinity receptor complex and thus attenuates trkA-mediated NGF signaling (Miller et al., 1994). The idea that $\mathrm{p} 75^{\mathrm{NTR}}$ plays a role in the sequestration of NGF on sympathetic terminals is supported by two lines of evidence. First, examining the dissociation of ${ }^{125} \mathrm{I}-\mathrm{NGF}$ from distal axons of sympathetic neurons in compartmented cultures, Ure and Campenot (1997) reported that $\sim 85 \%$ of axon-associated NGF is surface-bound, only a portion of which is associated with very slow dissociating (high affinity) sites. Second, sympathetic axons that sprout into an NGF-rich tissue display NGF immunoreactivity (Yu and Crutcher, 1995; Coome et al., 1998). This NGF immunostaining at sympathetic terminal axons is dramatically reduced in the absence of $\mathrm{p} 75^{\mathrm{NTR}}$ (Coome et al., 1998). Another possible outcome of $\mathrm{p} 75^{\mathrm{NTR}}$-mediated sequestration of NGF on distal axons is that $\mathrm{p} 75^{\mathrm{NTR}}-\mathrm{NGF}$ receptor-ligand complexes sterically interfere with axon-axon interactions mediated by cell adhesion molecules. Although it is conceivable that factors that inhibit fasciculation could reduce axonal growth responses, there is little evidence supporting such a role for $\mathrm{p} 75^{\mathrm{NTR}}$.

Finally, the possibility that $\mathrm{p} 75^{\mathrm{NTR}}$ modulates NGF signaling and collateral sprouting responses by directly activating an intracellular pathway should not be ruled out. Recent studies, using cell lines expressing $\mathrm{p} 75^{\mathrm{NTR}}$ in the absence of detectable levels of trkA, have demonstrated that ligand binding of $\mathrm{p} 75^{\mathrm{NTR}}$ can result in the activation and nuclear translocation of the transcription factor NF- $\kappa \mathrm{B}$ (Carter et al., 1996), enhancement of jun kinase activity (Casaccia-Bonnefil et al., 1996), and generation of ceramide (Dobrowsky et al., 1994, 1995; Casaccia-Bonnefil et al., 1996). In fact, increased levels of ceramide in the distal neurites of sympathetic neurons perturbs new growth of these fibers (de Chaves et al., 1997). Furthermore, BDNF-mediated activation of $\mathrm{p} 75^{\mathrm{NTR}}$ signaling leads to apoptosis during the period of naturally occurring cell death among sympathetic neurons (Bamji et al., 1998). That such a mechanism could account for our observations of enhanced sympathetic sprouting in the absence of $\mathrm{p} 75^{\mathrm{NTR}}$ remains to be elucidated. Interestingly, addition of BDNF has been shown to inhibit NGF-induced growth of sensory axons (Kimpinski et al., 1997). This study, however, did not examine whether this inhibition was a direct result of $\mathrm{p} 75^{\mathrm{NTR}}$ mediated signaling. In addition, loading PC12 cells and embryonic sensory neurons with a peptide, identical to a region of the cytoplasmic domain of $\mathrm{p} 75^{\mathrm{NTR}}$, modulates NGF-induced neurite outgrowth in a manner that appears to be mediated downstream of the ligand-receptor level (Dostaler et al., 1996).

In sum, our data provide evidence demonstrating that supplementation of NGF can elicit the growth of sympathetic axons within myelinated environments of the adult mammalian brain. Furthermore, our results indicate that the growth of sympathetic axons in response to elevated levels of NGF is enhanced when the function of the $\mathrm{p} 75^{\mathrm{NTR}}$ is neutralized. These findings of NGFinduced growth of peripheral axons provide encouragement that similar elongation of CNS axons in myelinated environments of the adult brain is possible in response to other neurotrophins, such as BDNF and NT-3, especially when $\mathrm{p} 75^{\mathrm{NTR}}$ function is perturbed.

\section{REFERENCES}

Bamji SX, Majdan M, Pozniak CD, Belliveau DJ, Aloyz R, Kohn J, Causing CG, Miller FD (1998) The p75 neurotrophin receptor mediates neuronal apoptosis and is essential for naturally occurring sympathetic neuron death. J Cell Biol 140:911-923.

Barker PA, Shooter EM (1994) Disruption of NGF binding to the low affinity neurotrophin receptor p75LNTR reduces NGF binding to TrkA on PC12 cells. Neuron 13:203-215.

Bregman BS, Kunkel-Bagden E, Schnell L, Dai HN, Gao D, Schwab ME (1995) Regrowth of injured adult corticospinal and brainstem-spinal fibers elicited by antibodies to neurite growth inhibitors leads to recovery of locomotor function after spinal cord injury. Nature 378:498-501.

Bregman BS, McAtee M, Dai HN, Kuhn PL (1997) Neurotrophic factors increase axonal growth after spinal cord injury and transplantation in the adult rat. Exp Neurol 148:475-494.

Caroni P, Schwab ME (1988a) Antibody against myelin-associated inhibitor of neurite growth neutralizes nonpermissive substrate properties of CNS white matter. Neuron 1:85-96.

Caroni P, Schwab ME (1988b) Two membrane protein fractions from rat central myelin with inhibitory properties for neurite growth and fibroblast spreading. J Cell Biol 106:1281-1288.

Carter BD, Kaltschmidt C, Kaltschmidt B, Offenhauser N, BohmMatthaei R, Baeuerle PA, Barde Y-A (1996) Selective activation of NF-kappaB by nerve growth factor through the neurotrophin receptor p75. Science 272:542-545.

Casaccia-Bonnefil P, Carter BD, Dobrowsky RT, Chao MV (1996) Death of oligodendrocytes mediated by the interaction of nerve growth factor with its receptor p75. Nature 383:716-719.

Chao MV, Hempstead BL (1995) p75 and Trk: a two receptor system. Trends Neurosci 18:321-326.

Coggeshall RE, Chung K, Greenwood D, Hulsebosch CE (1984) An empirical method for converting nucleolar counts to neuronal numbers. J Neurosci Methods 12:125-132.

Coome GEA, Kawaja MD (1999) Prolonged exposure to elevated levels of endogenous nerve growth factor affect the morphological and neurochemical features of sympathetic neurons of post-natal and adult mice. Neuroscience, in press.

Coome GEA, Elliott J, Kawaja MD (1998) Sympathetic and sensory axons invade the brains of nerve growth factor transgenic mice in the absence of p75 ${ }^{\text {NTR }}$ expression. Exp Neurol 148:284-294.

Crutcher KA (1989) Tissue sections from the mature rat brain and spinal cord as substrates for neurite outgrowth in vitro: extensive growth on gray matter but little growth on white matter. Exp Neurol 104:39-54. 
Crutcher KA, Chandler JP (1985) Evidence for sprouting specificity following medial septal lesions in the rat. J Comp Neurol 237:116-126.

Crutcher KA, Marfurt CF (1988) Nonregenerative axonal growth within the mature mammalian brain: ultrastructural identification of sympathohippocampal sprouts. J Neurosci 8:2289-2302.

Crutcher KA, Brothers L, Davis JN (1981) Sympathetic noradrenergic sprouting in response to central cholinergic denervation: a histochemical study of neuronal sprouting in the rat hippocampal formation. Brain Res 210:115-128.

Crutcher KA, Scott SA, Liang S, Everson WV, Weingartner J (1993) Detection of NGF-like activity in human brain tissue: increased levels in Alzheimer's disease. J Neurosci 13:2540-2550.

Davies AM, Lee K-F, Jaenisch R (1993) p75-deficient trigeminal sensory neurons have altered response to NGF but not to other neurotrophins. Neuron 11:565-574.

Davies SJA, Fitch MT, Memberg SP, Hall AK, Raisman G, Silver J (1997) Regeneration of adult axons in white matter tracts of the central nervous system. Nature 390:680-683.

de Chaves EIP, Bussiere M, Vance DE, Campenot RB, Vance JE (1997) Elevation of ceramide within distal neurites inhibits neurite growth in cultured rat sympathetic neurons. J Cell Biol 272:3028-3035.

Dobrowsky RT, Werner MH, Castellino AM, Chao MV, Hannun YA (1994) Activation of the sphingomyelin cycle through the low-affinity neurotrophin receptor. Science 265:1596-1599.

Dobrowsky RT, Jenkins GM, Hannun YA (1995) Neurotrophins induce sphingomyelin hydrolysis-modulation by coexpression of p $75^{\mathrm{NTR}}$ with trk receptors. J Biol Chem 270:22135-22142.

Dostaler SM, Ross GM, Myers SM, Weaver DF, Ananthanarayanan V, Riopelle RJ (1996) Characterization of a distinct motif of the low molecular weight neurotrophin receptor that modulates NGF-mediated neurite growth. Eur J Neurosci 8:870-879.

Fawcett J (1994) Astrocytes and axon regeneration in the central nervous system. J Neurol 242:S25-S28.

Fischer G, Künemund V, Schachner M (1986) Neurite out-growth patterns in cerebellar microexplant cultures are affected by antibodies to the cell surface glycoprotein L1. J Neurosci 6:602-612.

Foran D, Peterson AC (1992) Myelin acquisition in the central nervous system of the mouse revealed by an MBP-Lac $\mathrm{Z}$ transgene. J Neurosci 12:4890-4897.

Greene LA, Kaplan DR (1995) Early events in neurotrophin signalling via Trk and p75 receptors. Curr Opin Neurobiol 5:579-587.

Grill R, Murai K, Blesch A, Gage FH, Tuszynski MH (1997) Cellular delivery of neurotrophin-3 promotes corticospinal axonal growth and partial functional recovery after spinal cord injury. J Neurosci 17:5560-5572.

Hamano K, Iwasaki N, Takeya T, Takita H (1996) A quantitative analysis of rat central nervous system myelination using the immunohistochemical method for MBP. Brain Res 93:18-22.

Hantzopoulos PA, Suri C, Glass DJ, Goldfarb MP, Yancopoulos GD (1994) The low affinity NGF receptor, p75, can collaborate with each of the trks to potentiate functional responses to the neurotrophins. Neuron 13:187-201.

Kawaja MD (1998) Sympathetic and sensory innervation of the extracerebral vasculature: roles for $\mathrm{p} 75^{\mathrm{NTR}}$ neuronal expression and targetderived nerve growth factor. J Neurosci Res 52:295-306.

Kawaja MD, Crutcher KA (1997) Sympathetic axons invade the brains of mice overexpressing nerve growth factor. J Comp Neurol 383:60-72.

Kawaja MD, Walsh GS, Petruccelli K, Coome GEA (1997) Sensory nociceptive axons invade the cerebellum of transgenic mice overexpressing nerve growth factor. Brain Res 774:77-86.

Kimpinski K, Campenot RB, Mearow K (1997) Effects of the neurotrophins nerve growth factor, neurotrophin-3, and brain-derived neurotrophic factor (BDNF) on neurite growth from adult sensory neurons in compartmented cultures. J Neurobiol 33:395-410.

Klein R (1994) Role of neurotrophins in mouse neuronal development. FASEB J 8:738-744.

Landry CF, Ivy GO, Brown IR (1990) Developmental expression of glial fibrillary acidic protein mRNA in the rat brain analyzed by in situ hybridization. J Neurosci Res 25:194-203.

Lachance C, Belliveau DJ, Barker PA (1997) Blocking nerve growth factor binding to the p75 neurotrophin receptor on sympathetic neurons transiently reduces trkA activation but does not affect neuronal survival. Neuroscience 81:861-871.

Lee K-F, Li E, Huber J, Landis SC, Sharpe AH, Chao MV, Jaenisch R
(1992) Targeted mutation of the gene encoding the low affinity NGF receptor $\mathrm{p} 75$ leads to deficits in the peripheral sensory nervous system. Cell 69:737-749.

Lee K-F, Bachman K, Landis S, Jaenisch R (1994a) Dependence on p75 for innervation of some sympathetic targets. Science 263:1447-1449.

Lee K-F, Davies AM, Jaenisch R (1994b) p75-deficient embryonic dorsal root sensory and neonatal sympathetic neurons display a decreased sensitivity to NGF. Development 120:1027-1033.

Loeb DM, Greene LA (1993) Transfection with trk restores "slow" NGF binding, efficient NGF uptake, and multiple NGF responses to NGFnonresponsive PC12 cell mutants. J Neurosci 13:2919-2929.

Loeb DM, Maragos J, Martin-Zanaca D, Chao MV, Parada LF, Greene LA (1991) The trk proto-oncogene rescues NGF responsiveness in mutant NGF-nonresponsive PC12 cell lines. Cell 66:961-966.

Logan A, Oliver JJ, Berry M (1994) Growth factors in CNS repair and regeneration. Prog Growth Factor Res 5:379-405.

Lozano AM, Labes M, Roder J, Roach A (1995) An antineuronal monoclonal antibody that reverses neurite growth inhibition by central nervous system myelin. J Neurosci Res 42:306-313.

Mamounas LA, Blue ME, Siuciak JA, Alter CA (1995) Brain-derived neurotrophic factor promotes the survival and sprouting of serotonergic axons in rat brain. J Neurosci 15:7929-7939.

McKeon RJ, Schreiber RC, Rudge JS, Silver J (1991) Reduction of neurite outgrowth in a model of glial scarring following CNS injury is correlated with the expression of inhibitory molecules on reactive astrocytes. J Neurosci 11:3398-3411.

Menesini-Chen MG, Chen JS, Levi-Montalcini R (1978) Sympathetic nerve fiber ingrowth in the central nervous system of neonatal rodents upon intracerebral NGF injections. Arch Ital Biol 116:53-84.

Miller FD, Speelman A, Mathew TC, Fabian J, Chang E, Pozniak C, Toma JG (1994) Nerve growth factor derived from terminals selectively increases the ratio of p75 to trkA receptors on mature sympathetic neurons. Dev Biol 161:206-217.

Reier PJ, Houle JD (1988) The glial scar: its bearing on axonal elongation and transplantation approaches to CNS repair. Adv Neurol 47:87-138.

Reier PJ, Eng LF, Jakeman L (1989) Reactive astrocyte and axonal outgrowth in the injured CNS: is gliosis really an impediment to regeneration? In: Neural regeneration and transplantation, pp 183-209. New York: Liss.

Ruit KG, Osborne PA, Schmidt RE, Johnson EM, Snider WD (1990) Nerve growth factor regulates sympathetic ganglion cell morphology and survival in the adult mouse. J Neurosci 10:2412-2419.

Saffran BN, Crutcher KA (1990) NGF-induced remodeling of mature uninjured axon collaterals. Brain Res 525:11-20.

Savio T, Schwab ME (1990) Lesioned corticospinal tract axons regenerate in myelin-free rat spinal cord. Proc Natl Acad Sci USA 87:4130-4133.

Sawai H, Clarke DB, Kittlerova P, Bray GM, Aguayo AJ (1996) Brainderived neurotrophic factor and neurotrophin- $4 / 5$ stimulate growth of axonal branches from regenerating retinal ganglion cells. J Neurosci 16:3887-3894.

Schnell L, Schwab ME (1990) Axonal regeneration in the rat spinal cord produced by an antibody against myelin-associated neurite growth inhibitors. Nature 343:269-272.

Schnell L, Schneider R, Kolbeck R, Barde Y-A, Schwab ME (1994) Neurotrophin-3 enhances sprouting of corticospinal tract during development and after adult spinal cord lesion. Nature 367:170-173.

Schwab ME (1990) Myelin-associated inhibitors of neurite growth and regeneration in the CNS. Trends Neurosci 13:452-456.

Schwab ME, Caroni P (1988) Oligodendrocytes and CNS myelin are nonpermissive substrates for neurite growth and fibroblast spreading in vitro. J Neurosci 8:2381-2393.

Schwab ME, Brösamle C (1997) Regeneration of lesioned corticospinal tract fibers in the adult spinal cord under experimental conditions. Spinal Cord 35:469-473.

Schwab ME, Kapf hammer JP, Bandtlow CE (1993) Inhibitors of neurite growth. Annu Rev Neurosci 16:565-595.

Schwartz M, Cohen A, Stein-Izsak C, Belkin M (1989) Dichotomy of the glial cell response to axonal injury and regeneration. FASEB J 3:2371-2378.

Tuszynski MH, Peterson DA, Ray J, Baird A, Nakahara Y, Gage FH 
(1994) Fibroblasts genetically modified to produce nerve growth factor induce robust neuritic ingrowth after grafting to the spinal cord. Exp Neurol 126:1-14.

Ure DR, Campenot RB (1997) Retrograde transport and steady-state distribution of 125I-nerve growth factor in rat sympathetic neurons in compartmented cultures. J Neurosci 17:1282-1290.

Vanek P, Thallmair M, Schwab ME, Kapfhammer JP (1998) Increased lesion-induced sprouting of corticospinal fibres in the myelin-free rat spinal cord. Eur J Neurosci 10:45-56.

Verdi JM, Birren SJ, Ibáñez CF, Persson H, Kaplan DR, Benedetti M, Chao MV, Anderson DJ (1994) p75LNGFR regulates trk signal transduction and NGF-induced neuronal differentiation in MAH cells. Neuron 12:733-745.
Walsh GS, Petruccelli K, Kawaja MD (1998) p75-deficient sensory axons are immunoreactive for the glycoprotein L1 in mice overexpressing nerve growth factor. Brain Res 798:184-194.

Xu XM, Guenard V, Kleitman N, Aebischer P, Bunge MB (1995) A combination of BDNF and NT-3 promotes supraspinal axonal regeneration into Schwann cell grafts in adult thoracic spinal cord. Exp Neurol 134:261-272.

Ye JH, Houle JD (1997) Treatment of the chronically injured spinal cord with neurotrophic factors can promote axonal regeneration from supraspinal neurons. Exp Neurol 143:70-81.

Yu C, Crutcher KA (1995) Nerve growth factor immunoreactivity and sympathetic sprouting in the rat hippocampal formation. Brain Res 672:55-67. 